\title{
Synthesis and characterization of 3-aryl-3-[4-aryl-1,2,3-selenadiazol- 5-yl]-2-phenyl-2-propenenitrile
}

\author{
Sivaperuman Saravanan, ${ }^{\text {a }}$ Shunmuganarayanan Athimoolam, \\ and Shanmugam Muthusubramanian ${ }^{\mathrm{a}, *}$ \\ ${ }^{a}$ Department of Organic Chemistry, School of Chemistry, Madurai Kamaraj University, \\ Madurai - 625 021, India \\ ${ }^{b}$ School of Physics, Madurai Kamaraj University, Madurai - 625 021, India \\ E-mail: muthumanian2001@yahoo.com
}

\begin{abstract}
The synthesis and characterization of a new set of selenadiazoles, 3-aryl-3-[4-aryl-1,2,3selenadiazol-5-yl]-2-phenyl-2-propenenitrile derived from corresponding semicarbazones have been reported. The structural features of selenadiazoles synthesized have been analyzed by ${ }^{1} \mathrm{H}$ NMR, ${ }^{13} \mathrm{C}$ NMR and X-ray techniques.
\end{abstract}

Keywords: $\mathrm{SeO}_{2}$ oxidation, 1,2,3-selenadiazoles, ${ }^{1} \mathrm{H}$ NMR, ${ }^{13} \mathrm{C}$ NMR, 2D NMR and X-ray diffraction

\section{Introduction}

Compounds possessing nitrile functionality act as $\mathrm{Ca}^{2+}$ channel blockers (Figure 1) and are the first drugs of choice for the management of Prinzmetal angina. ${ }^{1-3}$ Vasavada et al. reported the synthesis and screening of some new nitriles having pharmaceutically important 3aminopropionilide moiety towards antitubercular and antimicrobial activity. ${ }^{4}$ Gidaspov et al studied the in vitro cytotoxic activity of 4-(2'- $\mathrm{R}_{1}-4$ '- $\mathrm{R}_{2}-1,3,5$-triazin-6'-yl)-4,4-dinitrobutyric acid nitriles and methyl esters. ${ }^{5}$ In the synthesis of heterocyclic compounds, the cyano group has the most fruitful utility. The reaction of nitriles with various amines leading to nitrogen heterocycles like benzimidazole, ${ }^{6}$ imidazolines, ${ }^{7}$ pyrrole derivatives ${ }^{8}$ and the synthesis of amino heterocycles by Thorpe-Ziegler cyclization ${ }^{9}$ are a few significant examples for its utility. 


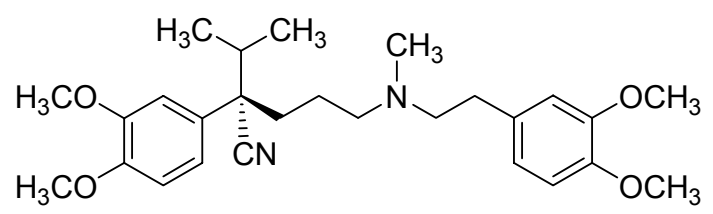

(S)-Verapamil

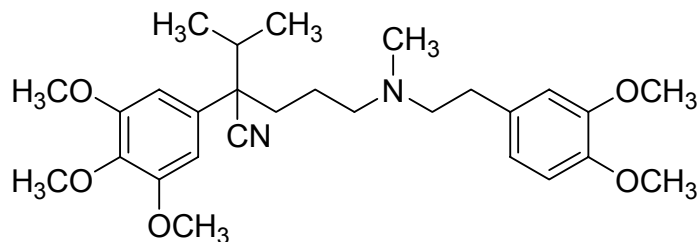

Gallopamil

Figure 1. Compounds containing nitrile functionality as calcium channel blockers.

Heterocyclic compounds containing selenium are of interest due to their biological and synthetic applications. Synthesis of 1,2,3- selenadiazoles is of recent interest as they are not only versatile intermediates for the preparation of alkynes and other selenium compounds, ${ }^{10}$ but also have attracted much attention for their biological characteristics like antifungal, antibacterial, antimicrobial and insecticidal activities. ${ }^{11}$ The chemistry of 1,2,3-selena/thiadiazoles has been recently reviewed by different workers. ${ }^{12}$ In continuation of our study on 1,2,3-selenadiazoles, ${ }^{13}$ we report the synthesis of yet another 1,2,3-selenadiazole system with a potential nitrile functionality in its skeleton and the target molecules are expected to have enhanced biological activity.

\section{Results and Discussion}

It has been planned to synthesise 3-aryl-3-(4-aryl-1,2,3-selenadiazol-5-yl)-2phenylpropanenitrile (Scheme 1) in the present investigation and carry out further transformations. Michael addition of benzyl cyanide to different chalcones $\mathbf{1}$ has led to the formation of the adduct 5-oxo-2,3,5-triarylpentanenitrile, $\mathbf{2}$. Though there is a possibility to get a mixture of diastereoisomers in these cases due to the presence of two adjacent stereocenters, only one diastereoisomer has been selectively obtained in all the cases. It should be mentioned that when ketones $\mathbf{2 b}, \mathbf{2 c}$ and $\mathbf{2 d}$ were treated with semicarbazide hydrochloride by the conventional procedure, the $E$ isomer of the semicarbazone alone has been obtained. However, in one case (3a), both the geometrical isomers have been obtained in the ratio of 1:3 (from ${ }^{1} \mathrm{H}$ NMR spectrum).

The semicarbazone, 2-[(E)-4-cyano-3-(4-methoxyphenyl)-1-(4-methylphenyl)-4phenylbutylidene]-1-hydrazinecarboxamide (3b) does not have a well defined pattern for the diasterotopic hydrogens and methine hydrogen in its ${ }^{1} \mathrm{H}$ NMR spectrum, preventing us from getting useful information regarding the conformation around $-\mathrm{CH}_{2}-\mathrm{CH}$ - system. But the single crystal X-ray analysis can be used to study the solid state conformational arrangement. The results are presented in Table 1 and the ORTEP and packing diagrams for $\mathbf{3 b}$ are shown in Figure 2 and Figure 3 respectively. ${ }^{14}$ 
Table 1. Crystal data and structural refinement for $\mathbf{3 b}$ and $\mathbf{4 a}$

\begin{tabular}{|c|c|c|}
\hline Parameters & $\mathbf{3 b}$ & $4 a$ \\
\hline Empirical formula & $\mathrm{C}_{26} \mathrm{H}_{26} \mathrm{~N}_{4} \mathrm{O}_{2}$ & $\mathrm{C}_{25} \mathrm{H}_{21} \mathrm{~N}_{3} \mathrm{Se}$ \\
\hline Temperature & 293(2) K & $293(2) \mathrm{K}$ \\
\hline Wavelength & $0.71073 \AA$ & $0.71069 \AA$ \\
\hline Crystal system & Monoclinic & Monoclinic \\
\hline Space group & $\mathrm{P} 21 / \mathrm{c}$ & $\mathrm{P} 21 / \mathrm{n}$ \\
\hline Unit cell dimensions & $\begin{array}{c}\mathrm{a}=9.215 \AA \\
\mathrm{b}=19.497 \AA \\
\mathrm{c}=13.227 \AA \\
\beta=94.80^{\circ}\end{array}$ & $\begin{array}{l}\mathrm{a}=12.492(5) \AA ; \\
\mathrm{b}=11.634(5) \AA ; \\
\mathrm{c}=15.640(5) \AA ; \\
\beta=104.535(5)^{\circ}\end{array}$ \\
\hline Volume & $2368.1 \AA^{3}$ & $2200.2(15) \AA^{3}$ \\
\hline $\mathrm{Z}$ & 4 & 4 \\
\hline Density (calculated) & $1.196 \mathrm{Mg} \mathrm{m}^{-3}$ & $1.336 \mathrm{Mg} \mathrm{m}^{-3}$ \\
\hline Absorption coefficient & $0.077 \mathrm{~mm}^{-1}$ & $1.722 \mathrm{~mm}^{-1}$ \\
\hline $\mathrm{F}(000)$ & 904 & 904 \\
\hline Crystal size & $0.22 \times 0.2 \times 0.17 \mathrm{~mm}$ & $0.21 \times 0.17 \times 0.15 \mathrm{~mm}$ \\
\hline $\begin{array}{l}\text { Theta range for data } \\
\text { collection }\end{array}$ & 2.09 to $24.98^{\circ}$ & 2.21 to $24.98^{\circ}$ \\
\hline Index ranges & $\begin{array}{c}0<=\mathrm{h}<=10,-1<=\mathrm{k}<=23, \\
-15<=1<=15\end{array}$ & $\begin{array}{c}0<=\mathrm{h}<=14,-1<=\mathrm{k}<=13, \\
-18<=1<=17\end{array}$ \\
\hline Reflections collected & 4701 & 4486 \\
\hline Independent reflections & $4153\left[\mathrm{R}_{\mathrm{int}}=0.0283\right]$ & $3865\left[\mathrm{R}_{\mathrm{int}}=0.0848\right]$ \\
\hline Absorption correction & Psi-scans & Psi-scans \\
\hline Refinement method & $\begin{array}{l}\text { Full-matrix least-squares } \\
\text { on } \mathrm{F}^{2}\end{array}$ & $\begin{array}{l}\text { Full-matrix least-squares on } \\
\qquad \mathrm{F}^{2}\end{array}$ \\
\hline Data / restraints / parameters & $4153 / 0 / 291$ & $3865 / 0 / 263$ \\
\hline Goodness-of-fit on $\mathrm{F}^{2}$ & 0.992 & 0.947 \\
\hline Final $R$ indices $[I>2 \sigma(I)]$ & $\mathrm{R}_{1}=0.0498, \mathrm{wR}_{2}=0.1046$ & $\mathrm{R}_{1}=0.0495, \mathrm{wR}_{2}=0.1080$ \\
\hline $\mathrm{R}$ indices (all data) & $\mathrm{R}_{1}=0.1642, \mathrm{wR}_{2}=0.1514$ & $\mathrm{R}_{1}=0.2249, \mathrm{wR}_{2}=0.1584$ \\
\hline Largest diff. peak and hole & 0.183 and $-0.172 \mathrm{e} \AA^{-3}$ & 0.468 and -0.647 e. $\AA^{-3}$ \\
\hline
\end{tabular}

In the solid state, the hydrogen on the $\mathrm{NH}_{2}$ and not the $\mathrm{NH}$ group of one molecule is involved in hydrogen bonding with the carbonyl oxygen of the other molecule thus forming a closed dimer or classical $\mathrm{R}_{2}^{2}(8)$ hydrogen bonding motif (N11-H11A $=0.860 \AA$, H11A...O11 $=2.090$ $\AA, \mathrm{N} 11 \ldots \mathrm{O} 11=2.926 \AA$ and N11-H11A...O11 = 163.6 ; symmetry code: $-\mathrm{x},-\mathrm{y},-\mathrm{z}+1)$ around 
the inversion centre of the unit cell as noticed in a related semicarbazone. ${ }^{15}$ It is also found that the imino carbon and the aryl group are gauche to each other with the $\mathrm{PhCHCN}$ group anti to imino carbon. The benzene rings are nearly perpendicular to the central $\mathrm{C}-\mathrm{C}-\mathrm{C}-\mathrm{C}$ linkage. The dihedral angles between the planes of the benzene rings are observed to be $69.0 / 60.6 / 50.4^{\circ}$.

The $E$ isomer has been subjected to selenium dioxide treatment in tetrahydrofuran (Scheme 1). The analysis of the reaction mixture after completion of the reaction has shown the formation of three products, differing widely in their $\mathrm{R}_{\mathrm{f}}$ values. They have been separated by column chromatography. One of the products has been found to be the original ketone 2 (less than $20 \%$ ) while the other two products, $\mathbf{4}$ and $\mathbf{5}$ have been identified as follows:
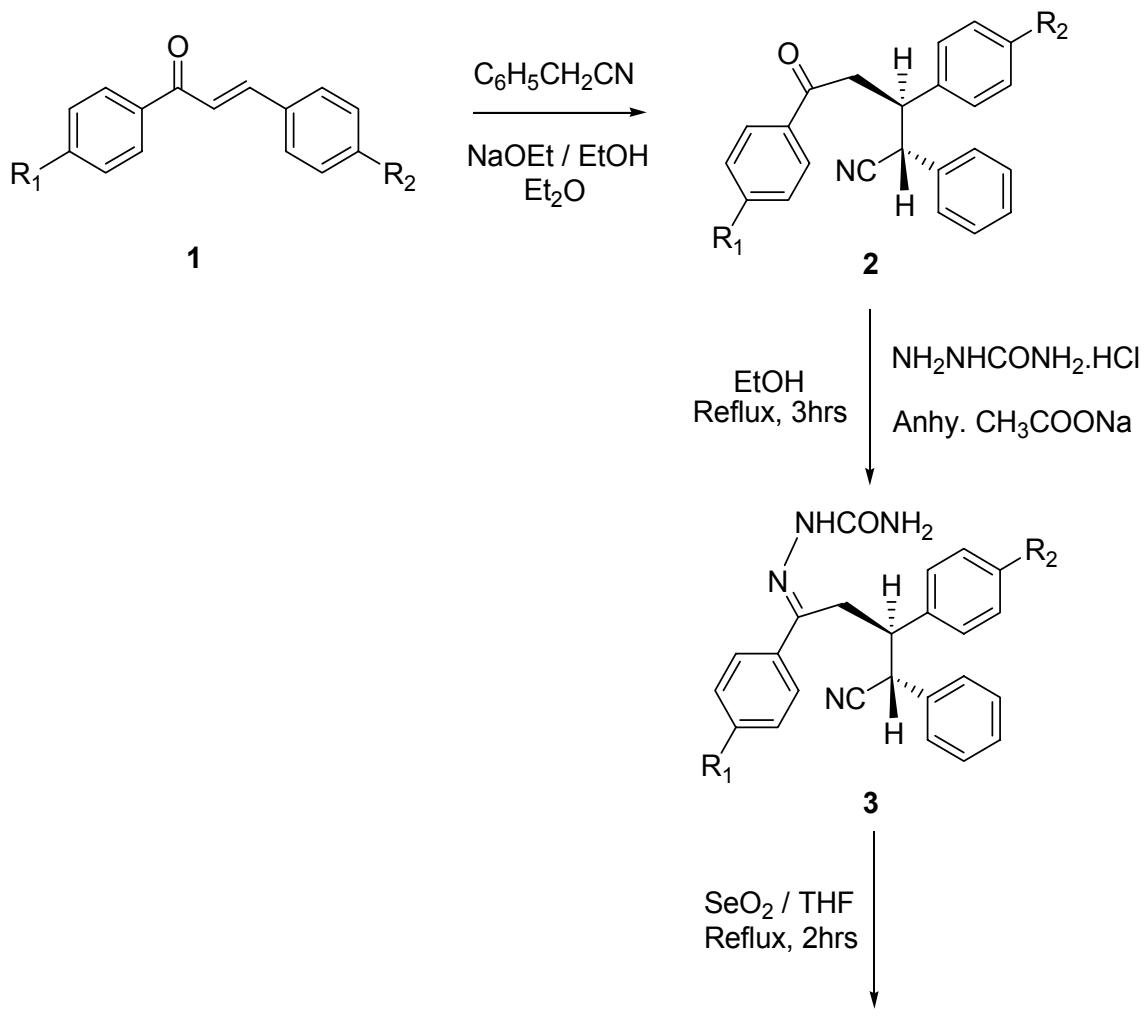

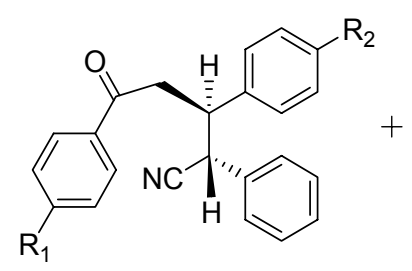

2

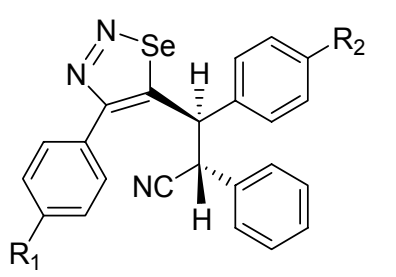

4<smiles>[R]c1ccc(C([N+]#N)=C(c2ccc([R])cc2)c2[se]nnc2-c2ccccc2)cc1</smiles>

5

$\begin{array}{lll} & \mathrm{R}_{1} & \mathrm{R}_{2} \\ \text { a } & \mathrm{CH}_{3} & \mathrm{CH}_{3} \\ \text { b } & \mathrm{CH}_{3} & \mathrm{OCH}_{3} \\ \text { c } & \mathrm{Cl} & \mathrm{OCH}_{3} \\ \text { d } & \mathrm{C}_{6} \mathrm{H}_{5} & \mathrm{H}\end{array}$

\section{Scheme 1}




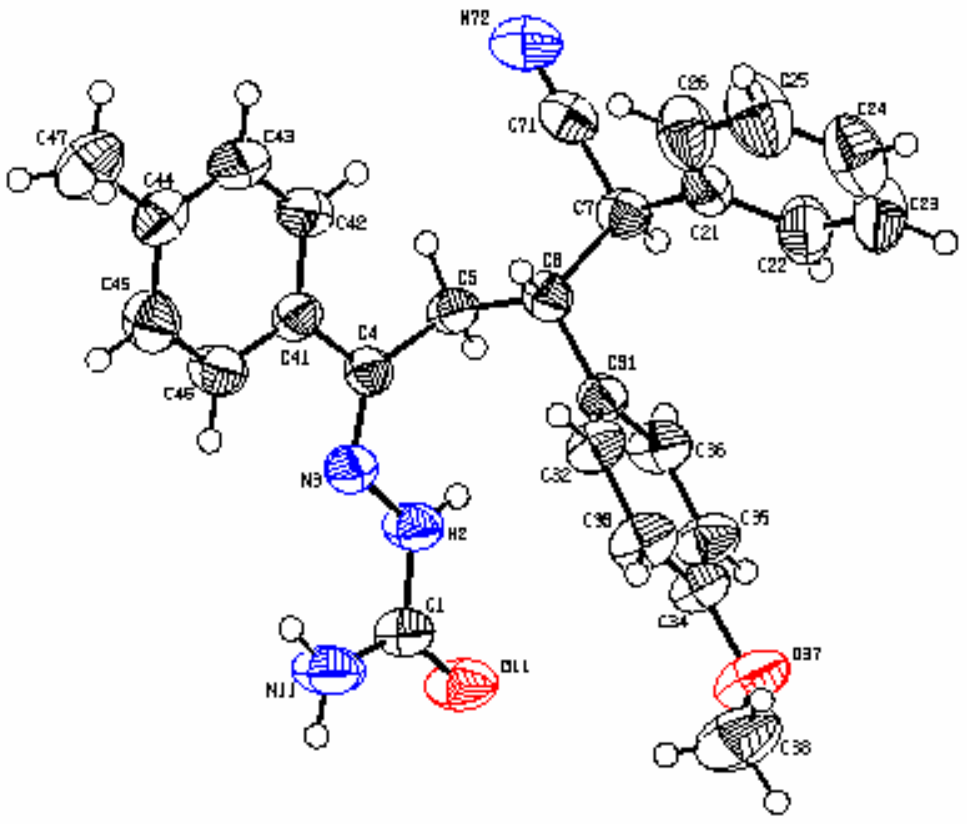

Figure 2. ORTEP diagram of 2-[(E)-4-cyano-3-(4-methoxyphenyl)-1-(4-methylphenyl)-4phenylbutylidene]-1-hydrazinecarboxamide (3b).

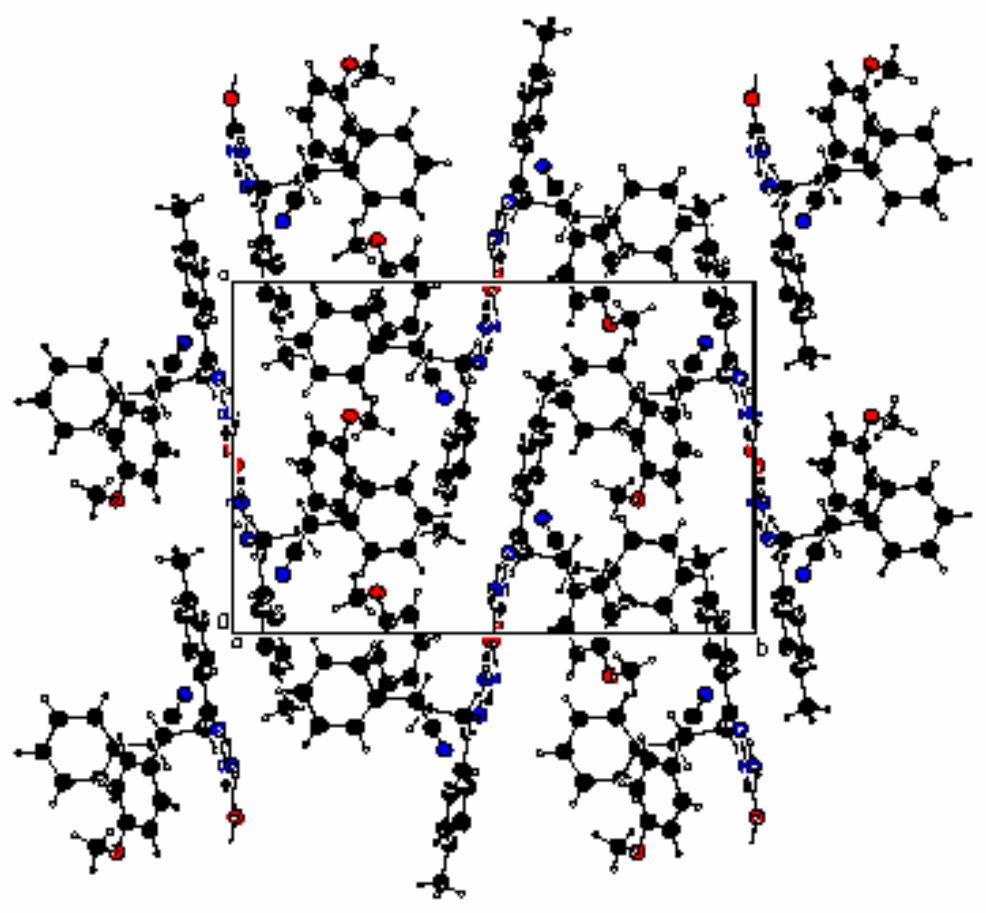

Figure 3. Packing diagram of 2-[(E)-4-cyano-3-(4-methoxyphenyl)-1-(4-methylphenyl)-4phenylbutylidene]-1-hydrazinecarboxamide (3b). 
${ }^{1} \mathrm{H}$ NMR spectrum of compound 4a shows two doublets at 4.28 and $4.89 \mathrm{ppm}$ with a coupling constant of $9.0 \mathrm{~Hz}$ apart from the methyl singlets with no other aliphatic hydrogens. This clearly shows the formation of selenadiazole unit and the ${ }^{13} \mathrm{C}$ NMR spectrum of $\mathbf{4 a}$ confirms this. The presence of quaternary carbons at 160.7 and 160.2 ppm clearly established the formation of selenadiazole ring and hence compound 4 has been identified as 3-aryl-3-(4aryl-1,2,3-selenadiazol-5-yl)-2-phenylpropanenitrile. The structure of $\mathbf{4 a}$ has been confirmed by single crystal X-ray analysis. ${ }^{16}$ The results are summarized in Table 1 and the ORTEP and packing diagrams are shown in Figure 4 and Figure 5 respectively.

The phenyl rings $\mathrm{C} 31-\mathrm{C} 36, \mathrm{C} 51-\mathrm{C} 56$ and $\mathrm{C} 61-\mathrm{C} 66$ make dihedral angles of $63.5^{\circ}, 62.3^{\circ}$ and $55.6^{\circ}$ respectively, with the selenadiazolyl ring (Se1/N1/N2/C3/C4). The C61-C6-C5-C51 and $\mathrm{C} 7-\mathrm{C} 6-\mathrm{C} 5-\mathrm{C} 51$ torsion angles of $174^{\circ}$ and $62^{\circ}$, show that the methylphenyl ring is in trans to the phenyl group and gauche to the $\mathrm{CN}$ group.

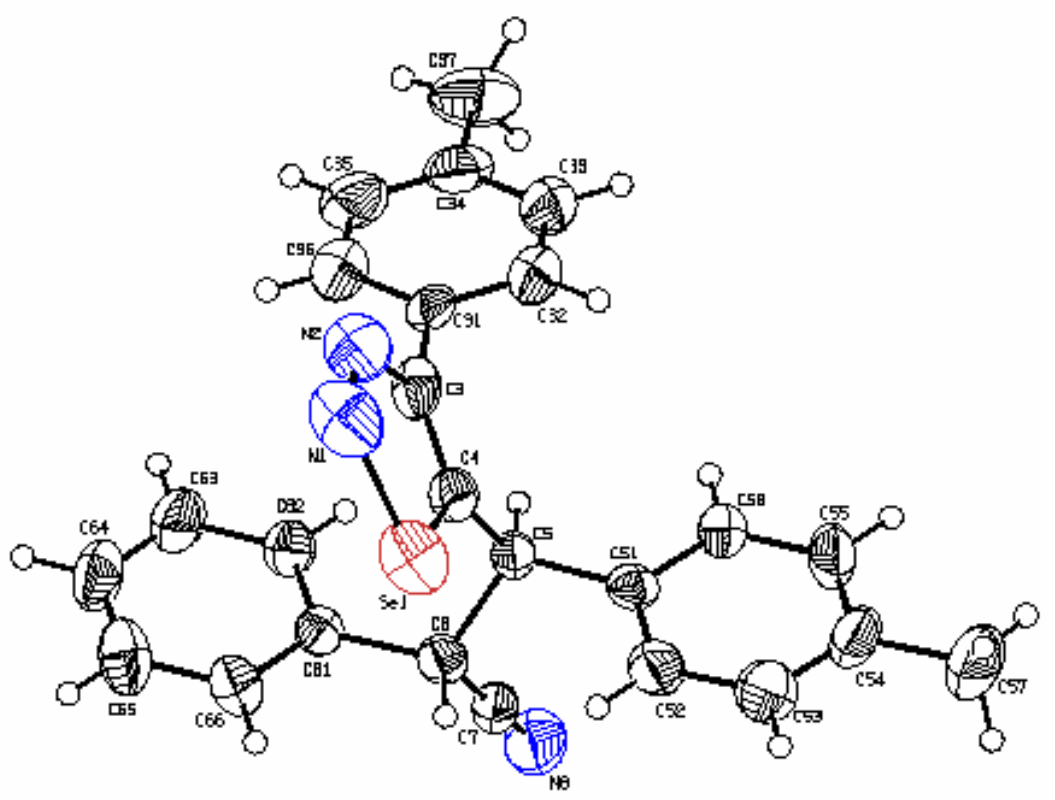

Figure 4. ORTEP diagram of 3-(4-methylphenyl)-3-[4-(4-methylphenyl)-1,2,3-selenadiazol-5yl]-2-phenylpropanenitrile (4a).

Compound 5 obtained as a minor product has only the aryl methyl hydrogens in the aliphatic regions with no benzylic or methine hydrogens. The presence of three aryl rings has been confirmed by the comparison of the area of hydrogens. The ${ }^{13} \mathrm{C}$ NMR spectrum of 5a has two additional olefinic carbons compared to $4 \mathbf{a}$. The aryl methyl carbon appears at 21.5 and 21.3 ppm, while the cyanide carbon appears at $114.2 \mathrm{ppm}$. The absence of two aliphatic carbons and the appearance of two additional olefinic carbons indicate that the side chain has been dehydrogenated after the initial formation of $\mathbf{4}$ from 3. Thus compound 5 is 3-aryl-3-(4-aryl1,2,3-selenadiazol-5-yl)-2-phenylpropanenitrile. It is obvious that selenium dioxide has effected 
the oxidation of the side chain in addition to the oxidative ring closure of the semicarbazone. A small amount of $\mathbf{4 a}$, when subjected to selenium dioxide treatment separately, gave 5a quantitatively indicating that the formation of selenadiazole ring could be the first step for the formation of $\mathbf{5}$. Compound $\mathbf{5}$ is nevertheless a very good synthetic precursor for further manipulation as it can act as a good dienophile. The formation of this dehydrogenated product in a tandem fashion, which is not observed in the other 1,2,3-selenadiazoles formation reported by us, ${ }^{13}$ can be accounted by the powerful electron withdrawing character of cyanide, which can stabilize the newly formed double bond by intense conjugation.

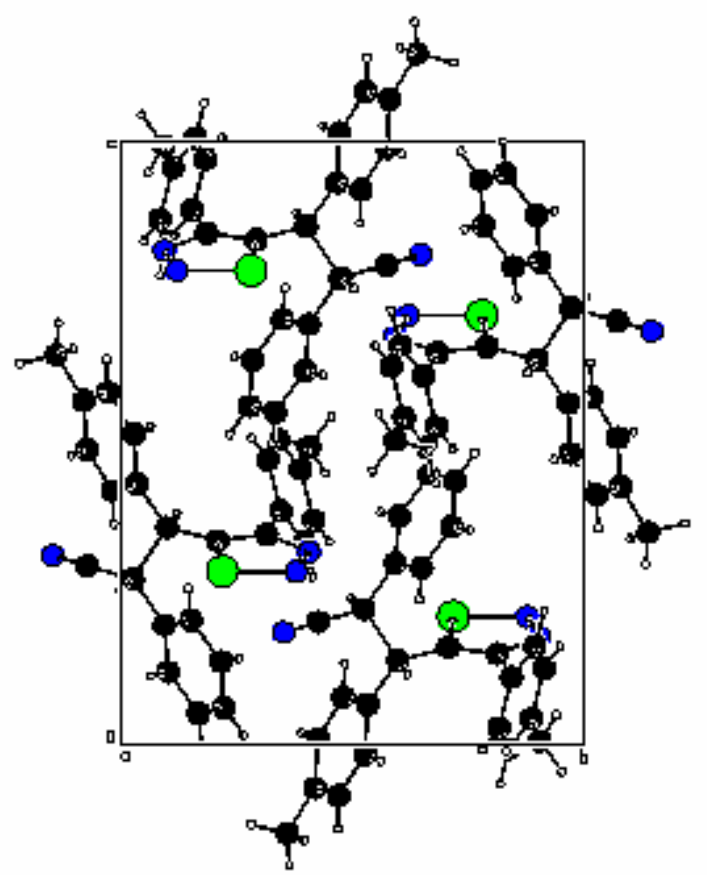

Figure 5. Packing diagram of 3-(4-methylphenyl)-3-[4-(4-methylphenyl)-1,2,3-selenadiazol-5yl]-2-phenylpropanenitrile (4a).

It should be mentioned that only one geometrical isomer is obtained in the case of $\mathbf{5}$, though $\mathrm{E}, \mathrm{Z}$ isomerism can be expected around olefinic double bond of the side chain. It is not possible to unambiguously assign the stereochemistry around the double bond with the available data. It is also not possible to assign all the carbons with the popular 2D techniques and hence the geometry around the olefinic bond is uncertain. Attempts to grow a crystal for this system are also not fruitful. Based on steric considerations, it can be assumed that the phenyl group and the tolyl group in 5a are away in trans- orientation suggesting the following arrangement for compound 5a (Figure 6). The fact that the cyano- group influences the absorption position of the ortho-hydrogens of the geminal aryl ring in the ${ }^{1} \mathrm{H}$ NMR spectrum is confirmed by the $\mathrm{H}, \mathrm{H}-$ COSY experiment in 5a. The most shielded aromatic hydrogen at $6.90 \mathrm{ppm}$ has connection with a contour, which has further connection with another set of hydrogen in the aryl ring. This is 
possible only when the signal at $6.90 \mathrm{ppm}$ is due to the ortho-hydrogens of the phenyl ring geminal to the cyano group.<smiles>Cc1ccc(/C(=C(\C#N)c2ccccc2)c2[se]nnc2-c2ccc(C)cc2)cc1</smiles>

Figure 6

\section{Experimental Section}

General Procedures. Melting points are uncorrected. ${ }^{1} \mathrm{H},{ }^{13} \mathrm{C}$, DEPT, H, H-COSY, C, H-COSY and $\mathrm{HMBC}$ spectra were recorded on a Bruker $300 \mathrm{MHz}$ instrument in $\mathrm{CDCl}_{3}$ using TMS as internal standard. Chemical shifts are given in parts per million ( $\delta$-scale) and coupling constants are given in Hertz. IR spectra were recorded on a JASCO FT-IR instrument using KBr pellets. The single crystal X-ray data were collected on a Nonius MACH3 kappa diffractometer with $\mathrm{MoK}_{\alpha}$ radiation $(\lambda=0.71073 \AA)$. The structure was solved by direct methods from SHELXS- 86 and refined by full matrix least squares on $\mathrm{F}^{2}$ by SHELXL-93.

\section{General procedure for the preparation of 5-0xo-2,3,5-triphenylpentanenitrile (2)}

Benzyl cyanide ( 0.06 mole) was added to different chalcones 1 ( 0.06 mole) in ether solution in presence of a small amount of sodium ethoxide $(0.012 \mathrm{~mole})$ in ethanol and the reaction mixture was kept at room temperature for about 20 hours. The solution was then acidified by adding a few drops of acetic acid and the precipitated white solid was recrystallised from ethanol to get $\mathbf{2}$.

\section{General procedure for the preparation of 2-[1,3-diaryl-4-cyano-4-phenylbutylidene]-1- hydrazinecarboxamide (3)}

To a warm solution of 0.01 moles of the appropriate ketone in $30 \mathrm{~mL}$ of ethanol, a solution of equimolar amount ( 0.07 moles) of semicarbazide hydrochloride and anhydrous sodium acetate in $20 \mathrm{~mL}$ of water was added and the mixture was refluxed for $4 \mathrm{hrs}$. The solution was cooled and poured onto crushed ice and extracted with chloroform. The solvent was evaporated and the product was recrystallised from ethanol.

The physical, analytical and spectral data of new 2-[1,3-diaryl-4-cyano-4-phenylbutylidene]-1hydrazinecarboxamide (3) are given below:

2-[(E)-4-Cyano-1,3-bis(4-methylphenyl)-4-phenylbutylidene]-1-hydrazine carboxamide (3a). Yield $=75 \%$; Mp $=193{ }^{\circ} \mathrm{C}$; IR (KBr) = $3486(w), 3371(w), 3029(w), 2921(w), 2239$ (w), 1681 (s), 1569 (s), 1454 (m), 1111 (w), 821 (w), 698 (w) cm ${ }^{-1}$; ${ }^{1} \mathrm{H}$ NMR $\left(\mathrm{CDCl}_{3}, 300 \mathrm{MHz}\right)$ 
$\delta=2.24(\mathrm{~s}, 3 \mathrm{H}), 2.35(\mathrm{~s}, 3 \mathrm{H}), 3.01-3.07(\mathrm{~m}, 1 \mathrm{H}), 3.19-3.30(\mathrm{~m}, 2 \mathrm{H}), 4.37(\mathrm{~d}, \mathrm{~J}=7.2 \mathrm{~Hz}, 1 \mathrm{H})$, 5.27 (bs, 1H), 5.85 (bs, 1H), 6.98 (s, 5H), 7.07 (d, J = 8.1 Hz, 2H), 7.13 (d, J = 8.1 Hz, 2H), 7.22 - $7.31(\mathrm{~m}, 4 \mathrm{H}) \mathrm{ppm} ;{ }^{13} \mathrm{C} \mathrm{NMR}\left(\mathrm{CDCl}_{3}, 75 \mathrm{MHz}\right) \delta=20.7$ (q), 20.8 (q), 30.6 (d), $42.8(\mathrm{~d}), 47.1$ (t), 119.6 (s), 125.9 (d), 127.6 (d), 127.8 (d), 128.3 (d), 128.5 (d), 128.6 (d), 128.7 (s), 129.9 (d), 134.0 (s), 134.7 (s), 137.0 (s), 138.4 (s), 146.7 (s), 157.9 (s) ppm.

Anal. Calcd. for $\mathrm{C}_{26} \mathrm{H}_{26} \mathrm{~N}_{4} \mathrm{O}$ : C, 76.07; H, 6.38; N, 13.65. Found: C, 76.35; H, 6.45; N, 13.72 .

2-[(E)-4-Cyano-3-(4-methoxyphenyl)-1-(4-methylphenyl)-4-phenylbutylidene]-1-

hydrazinecarboxamide (3b). Yield $=84 \%$; $\mathrm{Mp}=135^{\circ} \mathrm{C}$; IR (KBr) = $3480(\mathrm{w}), 3345(\mathrm{w}), 3030$ (w), 2935 (w), 2237 (w), 1703 (s), 1585 (s), 1442 (w), 1249 (s), 1182 (w), 1035 (w), 844 (m), $698(\mathrm{~m}) \mathrm{cm}^{-1} ;{ }^{1} \mathrm{H} \mathrm{NMR}\left(\mathrm{CDCl}_{3}, 300 \mathrm{MHz}\right) \delta=2.35(\mathrm{~s}, 3 \mathrm{H}), 3.21-3.29(\mathrm{~m}, 2 \mathrm{H}), 3.50(\mathrm{dd}, \mathrm{J}=$ 15.3, 12.6 Hz, 1H), 3.67 (s, 3H), 4.16 (d, J = 6.9 Hz, 1H), 5.44 (bs, 1H), 6.05 (bs, 1H), 6.66 (d, J $=8.7 \mathrm{~Hz}, 2 \mathrm{H}), 6.95(\mathrm{~d}, \mathrm{~J}=8.7 \mathrm{~Hz}, 2 \mathrm{H}), 7.07(\mathrm{~d}, \mathrm{~J}=8.1 \mathrm{~Hz}, 2 \mathrm{H}), 7.14-7.20(\mathrm{~m}, 5 \mathrm{H}), 7.25-7.28$ $(\mathrm{m}, 2 \mathrm{H}), 9.40(\mathrm{~s}, 1 \mathrm{H}) \mathrm{ppm} ;{ }^{13} \mathrm{C} \mathrm{NMR}\left(\mathrm{CDCl}_{3}, 75 \mathrm{MHz}\right) \delta=21.2(\mathrm{q}), 30.0$ (d), 43.8 (d), 47.5 (t), 55.1 (q), 113.9 (s), 120.0 (d), 126.3 (d), 128.1 (d), 128.2 (d), 128.8 (d), 128.9 (s), 129.0 (d), 129.8 (d), 134.1 (s), 134.4 (s), 138.8 (s), 147.2 (s), 158.4 (s), 158.9 (s) ppm.

Anal. Calcd. for $\mathrm{C}_{26} \mathrm{H}_{26} \mathrm{~N}_{4} \mathrm{O}_{2}$ : C, 73.22; H, 6.14; N, 13.14. Found: C, 73.13; H, 6.06; N, 13.12 .

2-[(E)-1-(4-Chlorophenyl)-4-cyano-3-(4-methoxyphenyl)-4-phenylbutylidene]-1-

hydrazinecarboxamide (3c). Yield = $82 \%$; $\mathrm{Mp}=172{ }^{\circ} \mathrm{C}$; IR (KBr) = $3498(\mathrm{~m}), 3381(\mathrm{~m}), 3042$ (w), 2929 (w), 2241 (w), 1681 (s), 1565 (s), $1456(\mathrm{~m}), 1253(\mathrm{w}), 1093(\mathrm{w}), 837(\mathrm{~m}), 698(\mathrm{~m}) \mathrm{cm}^{-}$ 1; ${ }^{1} \mathrm{H} \mathrm{NMR}\left(\mathrm{CDCl}_{3}, 300 \mathrm{MHz}\right) \delta=3.11(\mathrm{dd}, \mathrm{J}=12.9,3.6 \mathrm{~Hz}, 1 \mathrm{H}), 3.21-3.36(\mathrm{~m}, 2 \mathrm{H}), 3.70(\mathrm{~s}$, $3 \mathrm{H}), 4.40(\mathrm{~d}, \mathrm{~J}=6.6 \mathrm{~Hz}, 1 \mathrm{H}), 5.21(\mathrm{bs}, 1 \mathrm{H}), 6.13(\mathrm{bs}, 1 \mathrm{H}), 6.67(\mathrm{~d}, \mathrm{~J}=8.7 \mathrm{~Hz}, 2 \mathrm{H}), 6.94(\mathrm{~d}, \mathrm{~J}=$ $8.7 \mathrm{~Hz}, 2 \mathrm{H}), 7.15-7.30(\mathrm{~m}, 9 \mathrm{H}), 9.74(\mathrm{~s}, 1 \mathrm{H}) \mathrm{ppm} ;{ }^{13} \mathrm{C} \mathrm{NMR}\left(\mathrm{CDCl}_{3}, 75 \mathrm{MHz}\right) \delta=31.5(\mathrm{~d})$, 43.4 (d), 47.0 (t), 55.2 (q), 113.8 (s), 119.7 (d), 127.7 (d), 128.1 (d), 128.4 (d), 128.5 (d), 128.9 (s), 129.2 (d), 129.3 (d), 134.2 (s), 134.9 (s), 136.0 (s), 146.8 (s), 158.4 (s), 159.2 (s) ppm.

Anal. Calcd. for $\mathrm{C}_{25} \mathrm{H}_{23} \mathrm{ClN}_{4} \mathrm{O}_{2}$ : C, 67.18; H, 5.19; N, 12.54. Found: C, 66.89; H, 5.12; N, 12.64. 2-[(E)-1-[1,1'-Biphenyl]-4-yl-4-cyano-3,4-diphenylbutylidene]-1-hydrazine carboxamide (3d). Yield $=87 \%$; Mp = $136{ }^{\circ} \mathrm{C}$; IR $(\mathrm{KBr})=3494(\mathrm{~m}), 3379(\mathrm{~m}), 3031(\mathrm{w}), 2921(\mathrm{w}), 2239$ (w), 1681 (s), 1566 (s), 1454 (s), 1103 (w), 843 (w), 761 (m), 704 (s) cm ${ }^{-1}$; ${ }^{1} \mathrm{H} \mathrm{NMR}\left(\mathrm{CDCl}_{3}, 300\right.$ $\mathrm{MHz}) \delta=3.05-3.14(\mathrm{~m}, 1 \mathrm{H}), 3.32-3.44(\mathrm{~m}, 1 \mathrm{H}), 4.56(\mathrm{~d}, \mathrm{~J}=7.5 \mathrm{~Hz}, 1 \mathrm{H}), 2.11$ (bs, 2H), 7.16 $(\mathrm{s}, 5 \mathrm{H}), 7.27-7.38(\mathrm{~m}, 8 \mathrm{H}), 7.44(\mathrm{~d}, \mathrm{~J}=7.8 \mathrm{~Hz}, 2 \mathrm{H}), 7.50(\mathrm{~d}, \mathrm{~J}=8.4 \mathrm{~Hz}, 2 \mathrm{H}), 7.61(\mathrm{~d}, \mathrm{~J}=8.4$ $\mathrm{Hz}, 2 \mathrm{H}), 9.63(\mathrm{~s}, 1 \mathrm{H}) \mathrm{ppm} ;{ }^{13} \mathrm{C} \mathrm{NMR}\left(\mathrm{CDCl}_{3}, 75 \mathrm{MHz}\right) \delta=30.2(\mathrm{~d}), 42.1(\mathrm{~d}), 46.9$ (t), $119.3(\mathrm{~s})$, 126.0 (d), 125.9 (d), 126.1 (d), 126.8 (d), 127.0 (d), 127.3 (d), 127.4 (d), 127.5 (d), 127.6 (d), 128.1 (d), 128.2 (d), 133.7 (s), 135.7 (s), 137.5 (s), 139.4 (s), 140.3 (s), 145.2 (s), 157.4 (s) ppm. Anal. Calcd. for $\mathrm{C}_{30} \mathrm{H}_{26} \mathrm{~N}_{4} \mathrm{O}$ : C, 78.58; H, 5.72; N, 12.22. Found: C, 78.45; H, 5.64; N, 12.34 .

\section{Reaction of semicarbazone (3) with selenium dioxide}

A solution of 0.005 mole of the appropriate semicarbazone and 0.05 mole of powdered selenium dioxide (used as such without purification) in dry THF was gently heated on a water bath for two hours. The selenium deposited on cooling was removed by filtration, and the filtrate was poured into crushed ice, extracted with chloroform, and purified by column chromatography using silica 
gel (60-120 mesh) with 97:3 petroleum ether: ethyl acetate as eluent to give the selenadiazoles 4 and 5, which were recrystallised from ethyl alcohol.

The physical, analytical and spectral data of the products 3-aryl-3-[4-aryl-1,2,3-selenadiazol-5yl]-2-phenylpropanenitrile (4) and (E)-3-aryl-3-[4-aryl-1,2,3-selenadiazol-5-yl]-2-phenyl-2propenenitrile (5) are given below:

3-(4-Methylphenyl)-3-[4-(4-methylphenyl)-1,2,3-selenadiazol-5-yl]-2-phenylpropane nitrile (4a). Yield $=40 \%$; Mp = $141{ }^{\circ} \mathrm{C}$; IR $(\mathrm{KBr})=3028(\mathrm{w}), 2920(\mathrm{w}), 2856(\mathrm{w}), 2241(\mathrm{w}), 1614$ (w), $1514(\mathrm{w}), 1456(\mathrm{w}), 1334(\mathrm{w}), 1255(\mathrm{w}), 1182(\mathrm{w}), 897(\mathrm{w}), 816(\mathrm{~m}), 752(\mathrm{w}), 698(\mathrm{~m}) \mathrm{cm}^{-}$ 1; ${ }^{1} \mathrm{H} \mathrm{NMR}\left(\mathrm{CDCl}_{3}, 300 \mathrm{MHz}\right) \delta=2.34(\mathrm{~s}, 3 \mathrm{H}), 2.44(\mathrm{~s}, 3 \mathrm{H}), 4.28(\mathrm{~d}, \mathrm{~J}=9.0 \mathrm{~Hz}, 1 \mathrm{H}), 4.89(\mathrm{~d}, \mathrm{~J}$ $=9.0 \mathrm{~Hz}, 1 \mathrm{H}), 6.92(\mathrm{~d}, \mathrm{~J}=7.8 \mathrm{~Hz}, 2 \mathrm{H}), 7.09(\mathrm{~d}, \mathrm{~J}=7.8 \mathrm{~Hz}, 2 \mathrm{H}), 7.17(\mathrm{~s}, 5 \mathrm{H}), 7.22$ - $7.27(\mathrm{~m}$, 4H) ppm; ${ }^{13} \mathrm{C} \mathrm{NMR}\left(\mathrm{CDCl}_{3}, 75 \mathrm{MHz}\right) \delta=21.1$ (q), 21.4 (q), 46.6 (d), 51.2(d), 118.7 (s), 127.8 (d), 128.0 (d), 128.2 (d), 128.7 (d), 128.9 (d), 129.4 (d), 129.6 (d), 130.1 (s), 132.6 (s), 135.5 (s), 138.5 (s), 139.1 (s), 160.2 (s), 160.7 (s) ppm.

Anal. Calcd. for $\mathrm{C}_{25} \mathrm{H}_{21} \mathrm{~N}_{3} \mathrm{Se}$ : C, 67.87; H, 4.78; N, 9.50. Found: C, 67.72; H, 4.67; N, 9.42.

3-(4-Methoxyphenyl)-3-[4-(4-methylphenyl)-1,2,3-selenadiazol-5-yl]-2-phenyl

propanenitrile (4b). Yield $=43 \%$; $\mathrm{Mp}=112{ }^{\circ} \mathrm{C}$; IR $(\mathrm{KBr})=3064(\mathrm{w}), 3028(\mathrm{w}), 2931(\mathrm{w})$, $2841(w), 2237$ (w), 1608 (w), 1512 (w), 1460 (w), 1259 (w), $1180(w), 1032$ (w), $820(\mathrm{~m}), 698$ (m) $\mathrm{cm}^{-1} ;{ }^{1} \mathrm{H} \mathrm{NMR}\left(\mathrm{CDCl}_{3}, 300 \mathrm{MHz}\right) \delta=2.42(\mathrm{~s}, 3 \mathrm{H}), 3.78(\mathrm{~s}, 3 \mathrm{H}), 4.35(\mathrm{~d}, \mathrm{~J}=6.9 \mathrm{~Hz}, 1 \mathrm{H})$, $4.97(\mathrm{~d}, \mathrm{~J}=6.9 \mathrm{~Hz}, 1 \mathrm{H}), 6.84(\mathrm{~d}, \mathrm{~J}=8.7 \mathrm{~Hz}, 2 \mathrm{H}), 6.98$ (d, J = 7.2 Hz, 2H), 7.08-7.13 (m, 4H), 7.18 - $7.26(\mathrm{~m}, 5 \mathrm{H}) \mathrm{ppm} ;{ }^{13} \mathrm{C} \mathrm{NMR}\left(\mathrm{CDCl}_{3}, 75 \mathrm{MHz}\right) \delta=21.4$ (q), $47.3(\mathrm{~d}), 51.2(\mathrm{~d}), 55.3$ (q), 114.5 (d), 118.9 (s), 127.8 (d), 128.5 (d), 128.6 (d), 128.9 (d), 129.1 (d), 129.4 (d), 129.7 (s), 130.0 (s), 132.6 (s), 138.9 (s), 157.8 (s), 159.3 (s), 161.7 (d) ppm.

Anal. Calcd. for $\mathrm{C}_{25} \mathrm{H}_{21} \mathrm{~N}_{3} \mathrm{OSe}$ : C, 65.50; H, 4.62; N, 9.17. Found: C, 65.62; H, 4.76; N, 9.20.

3-[4-(4-Chlorophenyl)-1,2,3-selenadiazol-5-yl]-3-(4-methoxyphenyl)-2-phenyl

propanenitrile (4c). Yield $=54 \% ; \mathrm{Mp}=147^{\circ} \mathrm{C}$; IR $(\mathrm{KBr})=3066(\mathrm{w}), 3031(\mathrm{w}), 2941(\mathrm{w})$, $2841(\mathrm{w}), 2241(\mathrm{w}), 1608(\mathrm{w}), 1514(\mathrm{w}), 1464(\mathrm{w}), 1252(\mathrm{w}), 1180(\mathrm{w}), 1030(\mathrm{w}), 837(\mathrm{~m}), 696$ (m) $\mathrm{cm}^{-1} ;{ }^{1} \mathrm{H}$ NMR $\left(\mathrm{CDCl}_{3}, 300 \mathrm{MHz}\right) \delta=3.81(\mathrm{~s}, 3 \mathrm{H}), 4.27(\mathrm{~d}, \mathrm{~J}=8.7 \mathrm{~Hz}, 1 \mathrm{H}), 4.81(\mathrm{~d}, \mathrm{~J}=8.7$ $\mathrm{Hz}, 1 \mathrm{H}), 6.90(\mathrm{~d}, \mathrm{~J}=8.7 \mathrm{~Hz}, 2 \mathrm{H}), 6.92(\mathrm{~d}, \mathrm{~J}=7.8 \mathrm{~Hz}, 2 \mathrm{H}), 7.13(\mathrm{~d}, \mathrm{~J}=8.4 \mathrm{~Hz}, 2 \mathrm{H}), 7.15(\mathrm{~d}, \mathrm{~J}=$ $8.7 \mathrm{~Hz}, 2 \mathrm{H}), 7.21(\mathrm{~d}, \mathrm{~J}=7.8 \mathrm{~Hz}, 2 \mathrm{H}), 7.28(\mathrm{tt}, \mathrm{J}=7.5,2.1 \mathrm{~Hz}, 1 \mathrm{H}), 7.42(\mathrm{~d}, \mathrm{~J}=8.4 \mathrm{~Hz}, 2 \mathrm{H}) \mathrm{ppm}$; ${ }^{13} \mathrm{C} \mathrm{NMR}\left(\mathrm{CDCl}_{3}, 75 \mathrm{MHz}\right) \delta=47.0(\mathrm{~d}), 51.1$ (d), 55.3 (q), 114.8 (d), 118.6 (s), 128.1 (d), 128.9 (d), 129.0 (d), 129.1 (d), 129.2 (d), 129.7 (d), 130.0 (s), 131.1 (s), 132.5 (s), 135.4 (s), 159.3 (s), 159.7 (s), 161.0 (s) ppm.

Anal. Calcd. for $\mathrm{C}_{24} \mathrm{H}_{18} \mathrm{ClN}_{3} \mathrm{OSe}$ : C, 60.20; H, 3.79; N, 8.78. Found: C, 60.38; H, 3.85; N, 8.86.

3-(4-[1,1'-Biphenyl]-4-yl-1,2,3-selenadiazol-5-yl)-2,3-diphenylpropanenitrile (4d). Yield = 52 \%; $\mathrm{Mp}=148{ }^{\circ} \mathrm{C}$; IR (KBr) = 3059 (w), 3030 (w), 2919 (w), $2854(\mathrm{w}), 2239$ (m), 1597 (w), 1492 (w), 1452 (w), 1269 (w), $1180(\mathrm{w}), 1030$ (w), 841 (m), 762 (s), 698 (s) cm ${ }^{-1} ;{ }^{1} \mathrm{H}$ NMR $\left(\mathrm{CDCl}_{3}\right.$, $300 \mathrm{MHz}) \delta=4.33(\mathrm{~d}, \mathrm{~J}=8.7 \mathrm{~Hz}, 1 \mathrm{H}), 5.00(\mathrm{~d}, \mathrm{~J}=8.7 \mathrm{~Hz}, 1 \mathrm{H}), 6.94(\mathrm{~d}, \mathrm{~J}=7.2 \mathrm{~Hz}, 2 \mathrm{H}), 7.18(\mathrm{t}$, $\mathrm{J}=7.8 \mathrm{~Hz}, 2 \mathrm{H}), 7.28-7.33(\mathrm{~m}, 5 \mathrm{H}), 7.38(\mathrm{~d}, \mathrm{~J}=7.5 \mathrm{~Hz}, 2 \mathrm{H}), 7.43(\mathrm{~d}, \mathrm{~J}=7.8 \mathrm{~Hz}, 2 \mathrm{H}), 7.51(\mathrm{t}, \mathrm{J}$ $=7.8 \mathrm{~Hz}, 2 \mathrm{H}), 7.67-7.71(\mathrm{~m}, 4 \mathrm{H}) \mathrm{ppm} ;{ }^{13} \mathrm{C} \mathrm{NMR}\left(\mathrm{CDCl}_{3}, 75 \mathrm{MHz}\right) \delta=46.2(\mathrm{~d}), 51.6(\mathrm{~d})$, 118.6 (s), 127.1 (d), 127.4 (d), 127.8 (d), 127.9 (d), 128.0 (d), 128.7 (d), 128.8 (d), 128.9 (d), 
129.0 (d), 129.4 (d), 129.9 (d), 130.1 (s), $132.4(\mathrm{~s}), 134.4$ (s), 140.1 (s), 141.9 (s), 160.2 (s), 160.5 (s) ppm.

Anal. Calcd. for $\mathrm{C}_{29} \mathrm{H}_{21} \mathrm{~N}_{3} \mathrm{Se}$ : C, 71.02; H, 4.32; N, 8.57. Found: C, 70.96; H, 4.28; N, 8.48.

(E)-3-(4-Methylphenyl)-3-[4-(4-methylphenyl)-1,2,3-selenadiazol-5-yl]-2-phenyl-2-

propenenitrile (5a). Yield $=15 \%$; $\mathrm{Mp}=128^{\circ} \mathrm{C}$; IR $(\mathrm{KBr})=3026(\mathrm{w}), 2923(\mathrm{w}), 2856(\mathrm{w})$, 2208 (w), 1606 (w), 1466 (w), 1232 (w), 1182 (w), 1020 (w), 819 (s), 694 (s) cm ${ }^{-1}$; ${ }^{1} \mathrm{H}$ NMR $\left(\mathrm{CDCl}_{3}, 300 \mathrm{MHz}\right) \delta=2.36(\mathrm{~s}, 3 \mathrm{H}), 2.39(\mathrm{~s}, 3 \mathrm{H}), 6.90(\mathrm{~d}, \mathrm{~J}=8.7 \mathrm{~Hz}, 2 \mathrm{H}), 7.05-7.11(\mathrm{~m}, 4 \mathrm{H})$, $7.15-7.23(\mathrm{~m}, 3 \mathrm{H}), 7.36(\mathrm{~d}, \mathrm{~J}=8.1 \mathrm{~Hz}, 2 \mathrm{H}), 7.48(\mathrm{~d}, \mathrm{~J}=8.1 \mathrm{~Hz}, 2 \mathrm{H}) \mathrm{ppm} ;{ }^{13} \mathrm{C} \mathrm{NMR}\left(\mathrm{CDCl}_{3}, 75\right.$ $\mathrm{MHz}) \delta=21.3(\mathrm{q}), 21.5$ (q), 114.2 (s), 119.0 (s), 128.1 (d), 128.4 (d), 128.5 (d), 128.6 (d), 128.9 (d), 129.0 (d), 129.3 (d), 129.5 (s), 133.8 (s), 135.4 (s), 139.1 (s), 141.5 (s), 147.5 (s), 154.9 (s), 160.2 (s) ppm.

Anal. Calcd. for $\mathrm{C}_{25} \mathrm{H}_{19} \mathrm{~N}_{3} \mathrm{Se}$ : C, 68.18; H, 4.35; N, 9.54. Found: C, 68.04; H, 4.26; N, 9.51.

(E)-3-(4-Methoxyphenyl)-3-[4-(4-methylphenyl)-1,2,3-selenadiazol-5-yl]-2-phenyl-2-

propenenitrile (5b). Yield $=12 \% ; \mathrm{Mp}=161{ }^{\circ} \mathrm{C}$; IR $(\mathrm{KBr})=3021(\mathrm{w}), 2924(\mathrm{w}), 2852(\mathrm{w})$, 2202 (w), 1603 (w), 1509 (s), 1465 (w), 1257 (w), 1178 (w), 1028 (w), 821 (m), 692 (m) cm ${ }^{-1}$; ${ }^{1} \mathrm{H} \mathrm{NMR}\left(\mathrm{CDCl}_{3}, 300 \mathrm{MHz}\right) \delta=2.37(\mathrm{~s}, 3 \mathrm{H}), 3.84(\mathrm{~s}, 3 \mathrm{H}), 6.89-6.93(\mathrm{~m}, 4 \mathrm{H}), 7.06-7.12(\mathrm{~m}$, 4H), $7.18(\mathrm{t}, \mathrm{J}=7.5 \mathrm{~Hz}, 1 \mathrm{H}), 7.37(\mathrm{~d}, \mathrm{~J}=8.1 \mathrm{~Hz}, 2 \mathrm{H}), 7.54(\mathrm{~d}, \mathrm{~J}=8.1 \mathrm{~Hz}, 2 \mathrm{H}) \mathrm{ppm} ;{ }^{13} \mathrm{C} \mathrm{NMR}$ $\left(\mathrm{CDCl}_{3}, 75 \mathrm{MHz}\right) \delta=21.3(\mathrm{q}), 55.4$ (q), 113.1 (s), 114.1 (d), 119.2 (s), 128.1 (d), 128.4 (d), 128.5 (d), 128.6 (d), 128.9 (d), 129.3 (d), 130.4 (s), 130.7 (s), 133.9 (s), 139.0 (s), 146.8 (s), 154.9 (s), 160.3 (s), 161.5 (s) ppm.

Anal. Calcd. for $\mathrm{C}_{25} \mathrm{H}_{19} \mathrm{~N}_{3} \mathrm{OSe}$ C, 65.79; H, 4.20; N, 9.21. Found: C, 65.84; H, 4.31; N, 9.26.

(E)-3-[4-(4-Chlorophenyl)-1,2,3-selenadiazol-5-yl]-3-(4-methoxyphenyl)-2-phenyl-2-

propenenitrile (5c). Yield $=16 \%$; $\mathrm{Mp}=154{ }^{\circ} \mathrm{C}$; IR $(\mathrm{KBr})=3023(\mathrm{w}), 2923(\mathrm{w}), 2854(\mathrm{w})$, 2205 (w), 1603 (w), 1466 (m), 1234 (m), 1028 (w), 896 (w), 845 (m), 821 (m), $694(\mathrm{~m}) \mathrm{cm}^{-1} ;{ }^{1} \mathrm{H}$ $\operatorname{NMR}\left(\mathrm{CDCl}_{3}, 300 \mathrm{MHz}\right) \delta=3.88(\mathrm{~s}, 3 \mathrm{H}), 7.01(\mathrm{~d}, \mathrm{~J}=8.7 \mathrm{~Hz}, 2 \mathrm{H}), 7.24-7.29(\mathrm{~m}, 5 \mathrm{H}), 7.46(\mathrm{~d}$, $\mathrm{J}=8.1 \mathrm{~Hz}, 2 \mathrm{H}), 7.81(\mathrm{~d}, \mathrm{~J}=8.7 \mathrm{~Hz}, 2 \mathrm{H}), 7.89(\mathrm{~d}, \mathrm{~J}=8.1 \mathrm{~Hz}, 2 \mathrm{H}) \mathrm{ppm} ;{ }^{13} \mathrm{C} \mathrm{NMR}\left(\mathrm{CDCl}_{3}, 75\right.$ $\mathrm{MHz}) \delta=55.8$ (q), 114.4 (d), 120.8 (s), 128.8 (s), 129.1 (d), 129.3 (d), 129.5 (d), 129.8 (d), 130.7 (d), 131.5 (d), 133.4 (s), 133.5 (s), 133.8 (s), 134.9 (s), 136.2 (s), 145.6 (s), 161.5 (s), 164.8 (s) ppm.

Anal. Calcd. for $\mathrm{C}_{24} \mathrm{H}_{16} \mathrm{ClN}_{3} \mathrm{OSe}$ : C, 60.45; H, 3.38; N, 8.81. Found: C, 60.69; H, 3.47; N, 8.70. (E)-3-(4-[1,1'-Biphenyl]-4-yl-1,2,3-selenadiazol-5-yl)-2,3-diphenyl-2-propenenitrile

(5d). Yield $=20 \% ; \mathrm{Mp}=136{ }^{\circ} \mathrm{C}$; IR $(\mathrm{KBr})=3029(\mathrm{w}), 2923(\mathrm{w}), 2854(\mathrm{w}), 2210(\mathrm{~m}), 1598(\mathrm{w})$, $1469(\mathrm{~m}), 1228(\mathrm{~m}), 896(\mathrm{w}), 845(\mathrm{w}), 759(\mathrm{w}), 694(\mathrm{~s}) \mathrm{cm}^{-1} ;{ }^{1} \mathrm{H} \mathrm{NMR}\left(\mathrm{CDCl}_{3}, 300 \mathrm{MHz}\right) \delta=$ $6.95(\mathrm{~d}, \mathrm{~J}=7.5 \mathrm{~Hz}, 2 \mathrm{H}), 7.10(\mathrm{t}, \mathrm{J}=7.8 \mathrm{~Hz}, 2 \mathrm{H}), 7.21(\mathrm{t}, \mathrm{J}=7.8 \mathrm{~Hz}, 1 \mathrm{H}), 7.37-7.51(\mathrm{~m}, 5 \mathrm{H})$, $7.50(\mathrm{~s}, 5 \mathrm{H}), 7.59-7.62(\mathrm{~m}, 4 \mathrm{H}) \mathrm{ppm} ;{ }^{13} \mathrm{C} \mathrm{NMR}\left(\mathrm{CDCl}_{3}, 75 \mathrm{MHz}\right) \delta=115.2$ (s), $118.7(\mathrm{~s})$, 127.0 (d), 127.3 (d), 127.8 (d), 128.5 (d), 128.6 (d), 128.8 (d), 128.9 (d), 129.0* (d), 129.3 (d), 129.8 (s), 130.9 (d), 133.6 (s), 138.3 (s), 140.1 (s), 141.7 (s), 147.1 (s), 155.3 (s), 159.9 (s) ppm.(*Two signals merge at that position)

Anal. Calcd. for $\mathrm{C}_{29} \mathrm{H}_{19} \mathrm{~N}_{3} \mathrm{Se}$ : C, 71.31; H, 3.92; N, 8.60. Found: C, 71.46; H, 3.97; N, 8.53. 


\section{Acknowledgements}

The authors thank DST, New Delhi for assistance under the IRHPA program for the NMR facility. We thank DST (FIST) New Delhi, for single crystal X-ray diffractometer facility. Financial support from CSIR, New Delhi to S Saravanan, SRF is gratefully acknowledged.

\section{References}

1. (a) Eichelbaum, M. Biochem. Pharmacol. 1988, 37, 93. (b) Echizen, H.; Brecht, T.; Neidergasass, S.; Volgelgesang, B.; Eichelbaum, M. Am. Heart J. 1985, 109, 210.

2. (a) Theodore, L. J.; Nelson, W. L. J. Org. Chem. 1987, 52, 1309. (b) Khurmi, N. S.; O 'Hara, M. J.; Bowles, M. J.; Subramanian, V. B.; Raftery, E. B. Am. J. Cardiol. 1984, 53, 684.

3. Brogden, R. N.; Benfield, P. Drugs 1994, 47, 93.

4. Vasavada, J. A.; Rajvaidya, S. P.; Parekh, H. H. J. Institution Chemists (India) 2002, 74, 88.

5. Gidaspov, A. A.; Bakharev, V. V.; Kachanovskaya, E. V.; Yakunina, N. G.; Bulychev, Yu. N. Pharm. Chem. J. 2002, 36, 366. Chem. Abstr. 2003, 139, 127494.

6. Grenda,V. J.; Jones, R. E.; Gal, G.; Sletzinger, M. J. Org. Chem. 1965, 30, 259.

7. Oxley, P.; Short, W. F. J. Chem. Soc. 1947, 497.

8. (a) Cocco, M. T.; Cogiu, C.; Onnis, V. J. Heterocycl. Chem. 1995, 32, 463. (b) Cocco, M. T.; Cogiu, C.; Onnis, V. J. Heterocycl. Chem. 1995, 32, 1679.

9. Gewald, K.; Bellmann, P.; Jansch, H. J. Liebigs. Ann. Chem. 1984, 1702; Chem. Abstr. 1985, $102,6077$.

10. (a) Ando, W.; Tokitoh, N. Heteroat. Chem. 1991, 1. (b) Al-Smadi, M.; Ratrout, S. J. Heterocycl. Chem. 2004, 41, 887.

11. (a) Faria, C.; Prizza, M.; Gramba, A.; Pifferri, G. I. Eur. J. Med. Chem-Chem. Ther. 1979, 14, 27. (b) Lalezari, I.; Shafiee, A.; Khorrami, J.; Soltani, A. J. Pharm. Sci. 1978, 67, 1336.(c) Kandeel, M. M.; El-Meligie, S.; Omar, R. H.; Roshdy, S. A.; Youssef, K. M. Chem. J. Pharm. Sci. 1994, 3, 197.

12. (a) Arsenyan, P.; Oberte, K.; Pudova, O.; Lukevics, E. Chem. Heterocycl. Compds. 2002, 38, 1437. (b) Morzherin, Y. Y.; Glukhareva, T. V.; Bakulev. V. A. Chem. Heterocycl. Compds. 2003, 39, 679. (c) Dehaen, W.; Bakulev, V. A.; Taylor, E. C.; Wipf, P. The Chemistry of Heterocyclic Compounds, Vol. 62, The chemistry of 1,2,3-thiadiazoles; John Wiley \& Sons, Inc., 2004, E-Book (ISBN 978-0-471-32662-5).

13. (a) Saravanan, S.; Nithya, A.; Muthusubramanian. S. J. Heterocycl. Chem. 2006, 43, 149. (b) Saravanan, S.; Muthusubramanian, S. Phosphorus Sulfur Silicon Relat. Elem. 2004, 179, 2411. (c) Saravanan, S.; Muthusubramanian, S.; Vasantha, S.; Sivakolunthu, S.; Raghavaiah, P. J. Sulfur Chem. (Accepted for publication)

14. Crystal data have been deposited to CCDC, number 613079

15. Saravanan, S.; Muthusubramanian, S.; Polborn, K. J. Mol. Struct. 2005, 748, 165.

16. Crystal data have been deposited to CCDC, number 613078. 